\title{
Preparation of needle-like aragonite particles from calcium nitrate solution in batch and flow reactors
}

\author{
Pavel Fellner, Jana Jurišová, Jana Kozánková, Ladislav Pach \\ Department of Inorganic Technology, Faculty of Chemical and Food Technology, \\ Slovak University of Technology, Radlinského 9, 81237 Bratislava, Slovak Republic \\ pavel.fellner@stuba.sk
}

\begin{abstract}
Needle-like aragonite particles for application in paper industry were synthesised from calcium nitrate solution. Calcium nitrate was prepared from waste lime. Samples of precipitated aragonite were prepared both in batch and flow reactors, respectively. Conditions (concentration of calcium nitrate, temperature, and flow rate of $\mathrm{CO}_{2}$ ) were optimized for achieving high yield of aragonite in the product.
\end{abstract}

Keywords: aragonite, precipitated calcium carbonate, calcium nitrate

\section{Introduction}

This study was aimed at preparing needle-like aragonite particles from calcium nitrate solution. Precipitated aragonite should be suitable for use in paper industry. In our previous work (Fellner et al. 2011) we studied the influence of organic substances as additives to the solution of "purum" grade calcium nitrate on the preparation of needle-like aragonite particles. Moreover, the literature survey on this topic was presented. In this paper we will refer about the results obtained in batch and flow reactors having volume $3 \mathrm{l}$, which can serve as a model for industrial reactors. Calcium nitrate used in this work was prepared from waste lime originating from treatment of calcium acetylide $\left(\mathrm{CaC}_{2}\right)$ with water under production of acetylene and $\mathrm{Ca}(\mathrm{OH})_{2}$.

As follows from our previous paper (Fellner et al. 2011), high yield of aragonite can be achieved at $(70 \pm 1)^{\circ} \mathrm{C}$. All experiments reported here were carried out at this temperature. Also the concentration of $\mathrm{Ca}\left(\mathrm{NO}_{3}\right)_{2}$ in the initial solution was constant, viz. 25 wt \%. In the cited work (Fellner et al. 2011) we found out that crucial parameter for preparation of aragonite is the activity $\mathrm{CO}_{2}$ in the solution. This can be managed by the rate of $\mathrm{CO}_{2}$ bubbled through the solution. When the activity of $\mathrm{CO}_{2}$ is too high, calcium carbonate precipitates as calcite. If it is too low, vaterite is obtained (Elfil and Roques 2001, Elfil and Roques 2004). However vaterite, if it is not stabilized by organic admixture, is rather unstable and it is easily transformed to calcite.

\section{Experimental}

$25 \mathrm{wt} \%$ solution of $\mathrm{Ca}\left(\mathrm{NO}_{3}\right)_{2}$ was prepared from waste lime according to the reaction scheme:

$$
\begin{gathered}
\mathrm{Ca}(\mathrm{OH})_{2}(\mathrm{~s})+2 \mathrm{NH}_{4} \mathrm{NO}_{3}(\mathrm{aq})= \\
=\mathrm{Ca}\left(\mathrm{NO}_{3}\right)_{2}(\mathrm{aq})+2 \mathrm{NH}_{3}(\mathrm{aq})+2 \mathrm{H}_{2} \mathrm{O}(\mathrm{l})
\end{gathered}
$$

Waste lime - suspension with content of $12 \mathrm{wt} \%$ $\mathrm{Ca}(\mathrm{OH})_{2}$ (total solids $13.4 \mathrm{wt} \%$ ) was processed with $\mathrm{NH}_{4} \mathrm{NO}_{3}$ (p.a. Mikrochem) under heating. After cooling the reaction mixture was filtered from the waste solid substances. Pure solution of $\mathrm{Ca}\left(\mathrm{NO}_{3}\right)_{2}$ was used to calcium carbonate precipitation according to the reaction scheme:

$$
\begin{gathered}
\mathrm{Ca}\left(\mathrm{NO}_{3}\right)_{2}(\mathrm{aq})+2 \mathrm{NH}_{3}(\mathrm{aq})+\mathrm{H}_{2} \mathrm{O}(\mathrm{l})+\mathrm{CO}_{2}(\mathrm{~g})= \\
=\mathrm{CaCO}_{3}(\mathrm{~s})+2 \mathrm{NH}_{4} \mathrm{NO}_{3}(\mathrm{aq})
\end{gathered}
$$

Two types of reactors were used: batch and flow reactors, respectively. Scheme of the flow reactor is shown in Fig. 1. Advantage of a flow reactor is that it makes it possible to keep the reaction conditions constant.

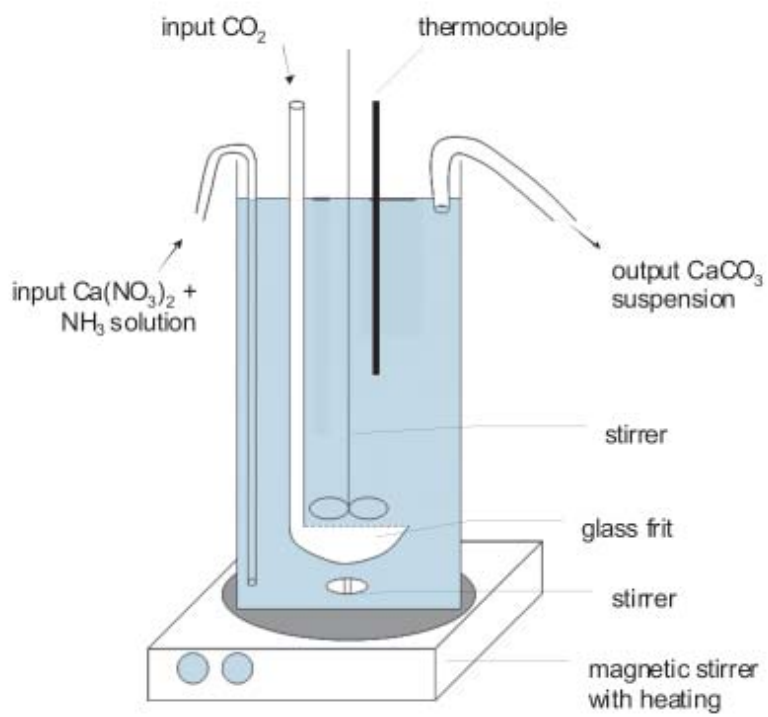

Fig. 1. Scheme of the flow reactor.

The reaction vessel was closed with a plastic cover. Mixing of the reaction mixture (solution of $\mathrm{Ca}\left(\mathrm{NO}_{3}\right)_{2}+\mathrm{NH}_{4} \mathrm{OH}\left(26 \mathrm{wt} \% \mathrm{NH}_{3}\right.$, p.a., Mikrochem) was performed by a magnetic stirrer $(450 \mathrm{rpm})$ and 
by an impeller stirrer. $\mathrm{CO}_{2}$ (gas cylinder, Messer) was introduced to the reaction mixture through glass frit (S3) which covered about one quarter of bottom of the reactor. Flow of $\mathrm{CO}_{2}$ was controlled by a calibrated rotameter. When the temperature of $25 \mathrm{wt} \% \mathrm{Ca}\left(\mathrm{NO}_{3}\right)_{2}$ solution with excess of $10 \mathrm{wt} \%$ $\mathrm{NH}_{3}$ achieved $70{ }^{\circ} \mathrm{C}, \mathrm{CO}_{2}$ was bubbled through the solution. Flow rate of $\mathrm{CO}_{2}$ was changed in the range $(1.2-6) \mathrm{dm}^{3} / \mathrm{min}$. Because of the reaction heat, temperature of the system increased during $20 \mathrm{~min}$ by $7^{\circ} \mathrm{C}$ and then gradually during $10 \mathrm{~min}$ decreased to $70^{\circ} \mathrm{C}$. The reaction was then stopped.
The batch reactor had the same geometry. The precipitate was decanted, filtered and washed with distilled water. Application in paper industry requires concentrated suspension of aragonite needles. This suspension was also used as a sample for scanning microscopy. For X-ray analysis, the samples were dried at $50{ }^{\circ} \mathrm{C}$. Powder X-ray analysis (STADI P, STOE) and SEM (Tesla BS 300 with digital unit Tescan) were used to characterize the product. Content of crystallographic phases of $\mathrm{CaCO}_{3}$ in samples was determined on the basis of X-ray diffraction. It can be estimated that the error is about $5 \%$.
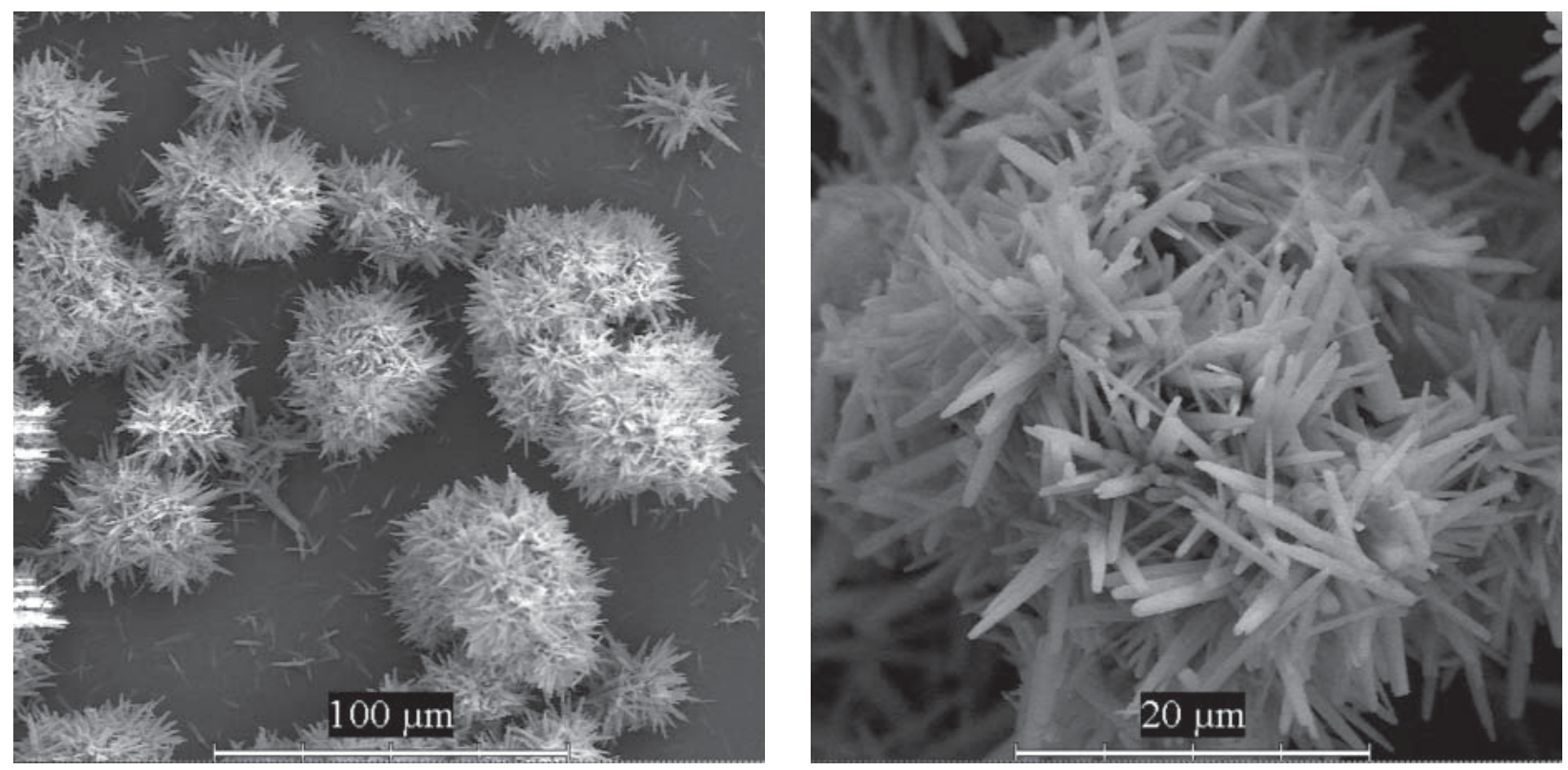

Fig. 2. SEM of $\mathrm{CaCO}_{3}$ particles prepared at $70{ }^{\circ} \mathrm{C} ; 2 \mathrm{dm}^{3} / \mathrm{min}$ flow rate of $\mathrm{CO}_{2}$; without ultrasound.
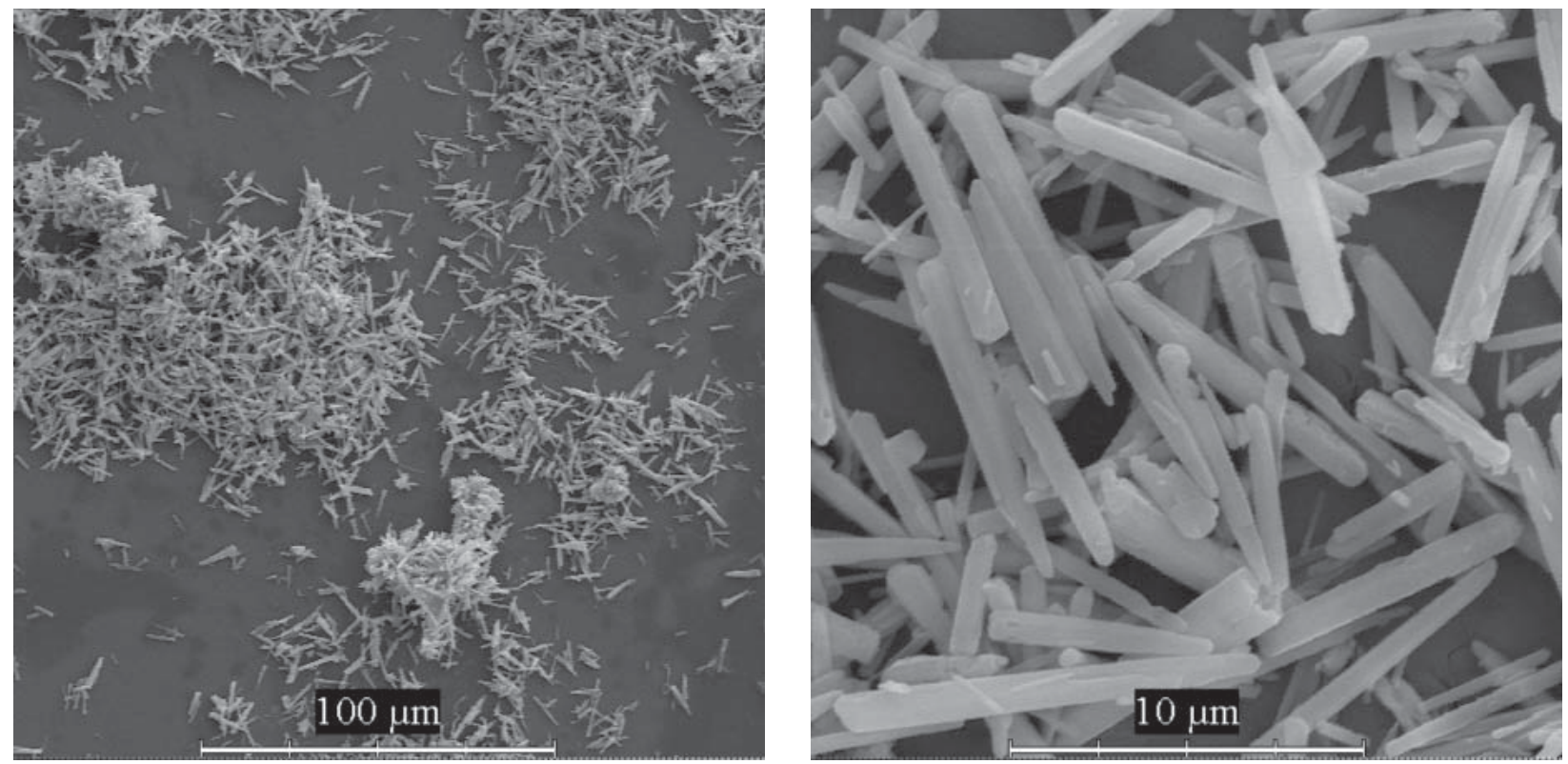

Fig. 3. SEM of $\mathrm{CaCO}_{3}$ particles prepared at $70{ }^{\circ} \mathrm{C} ; 2 \mathrm{dm}^{3} / \mathrm{min}$ flow rate of $\mathrm{CO}_{2}$; disintegrated by ultrasound for $15 \mathrm{~min}$. 


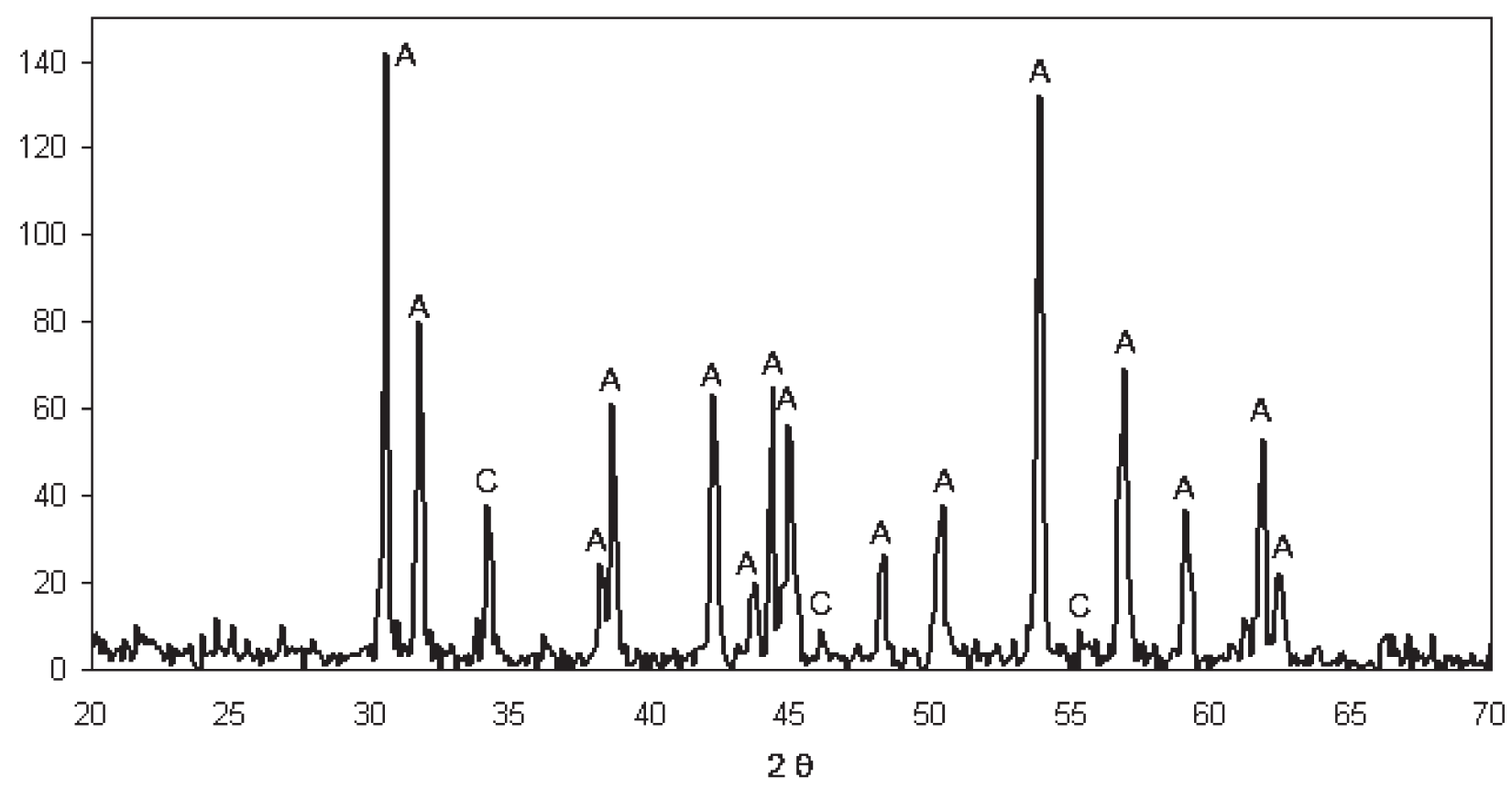

Fig. 4. X-ray diffraction of $\mathrm{CaCO}_{3}$ prepared at $70^{\circ} \mathrm{C} ; 2 \mathrm{dm}^{3} / \mathrm{min}$ flow rate of $\mathrm{CO}_{2} ; \mathrm{A}-$ aragonite, $\mathrm{C}-$ calcite.

\section{Results and Discussion}

\section{Batch reactor}

In the first series of experiments flow rate of $\mathrm{CO}_{2}$ was kept at $2 \mathrm{dm}^{3} / \mathrm{min}$. As can be seen from Figs. 2 aragonite needles were arranged in "balls" which could be easily disintegrated by ultrasound (see Fig. 3). X-ray diffraction indicated that the precipitate contained about $85 \%$ of aragonite (Fig. 4), the rest being calcite.

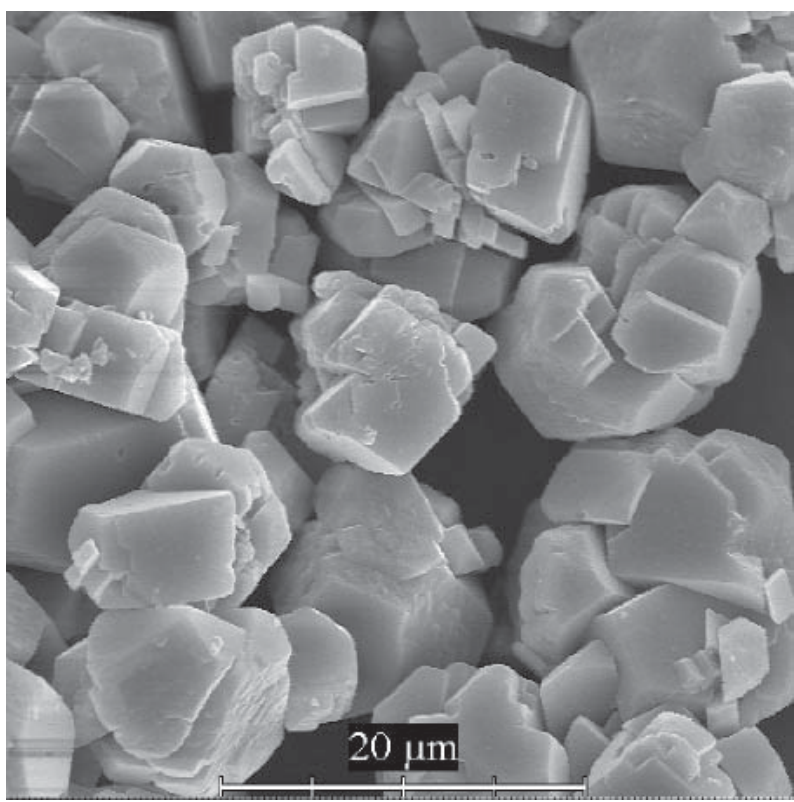

$6 \mathrm{dm}^{3} /$ min flow rate of $\mathrm{CO}_{2}$
In the next series of experiments flow of $\mathrm{CO}_{2}$ was increased to $6 \mathrm{dm}^{3} / \mathrm{min}$. The other parameters were the same as in the previous case. As evidenced by Fig. 5, in this case calcite (and not aragonite) was formed. The same result (exclusive calcite formation) was obtained when the flow of $\mathrm{CO}_{2}$ was reduced to $1.2 \mathrm{dm}^{3} / \mathrm{min}$. This can be explained by thermodynamic stability of calcite and aragonite phases which depends on the activity (concentration) of calcium cations in the solution and on the

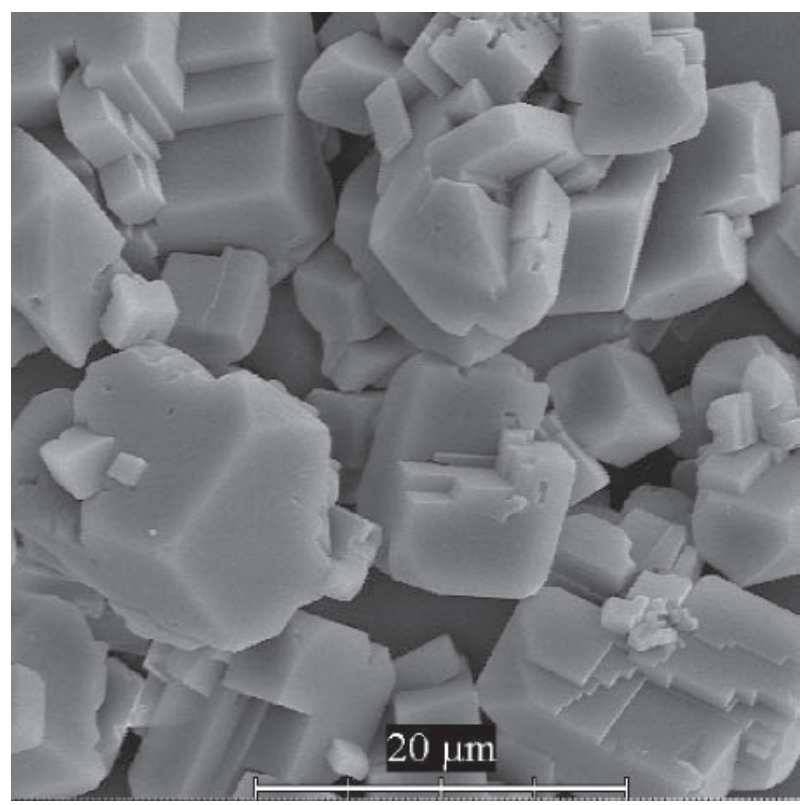

$1.2 \mathrm{dm}^{3} / \mathrm{min}$ flow rate of $\mathrm{CO}_{2}$

Fig. 5. SEM pictures of $\mathrm{CaCO}_{3}$ particles prepared at $70^{\circ} \mathrm{C}$. 
partial pressure of $\mathrm{CO}_{2}$ (Elfil and Roques 2001, Elfil and Roques 2004). The conditions for formation of aragonite presented in this paper correspond to used concentration of calcium nitrate $(25 \mathrm{wt} \%)$ and temperature $\left(70{ }^{\circ} \mathrm{C}\right)$.

The next experiment (the results are shown in Fig. 6) was identical with the previous one. However, in this case we took-off samples of precipitated $\mathrm{CaCO}_{3}$ regularly in intervals of several minutes. This experiment resulted in finding that nucleation of calcium carbonate continues during the whole process, not just in the beginning of $\mathrm{CaCO}_{3}$ precipi- tation. This idea was exploited at the realization of preparation of aragonite in a flow reactor.

\section{Flow reactor}

In this series of experiments, precipitation of $\mathrm{CaCO}_{3}$ started as in the batch reactor. In this batch mode the reactor worked for $40 \mathrm{~min}$. Then the reactants were supplied to the reactor continually and the product, suspension of precipitated $\mathrm{CaCO}_{3}$, was continually removed and analyzed. Solution of $\mathrm{Ca}\left(\mathrm{NO}_{3}\right)_{2}$ with ammonia was supplied by a peristaltic pump, $\mathrm{CO}_{2}$ was bubbled through

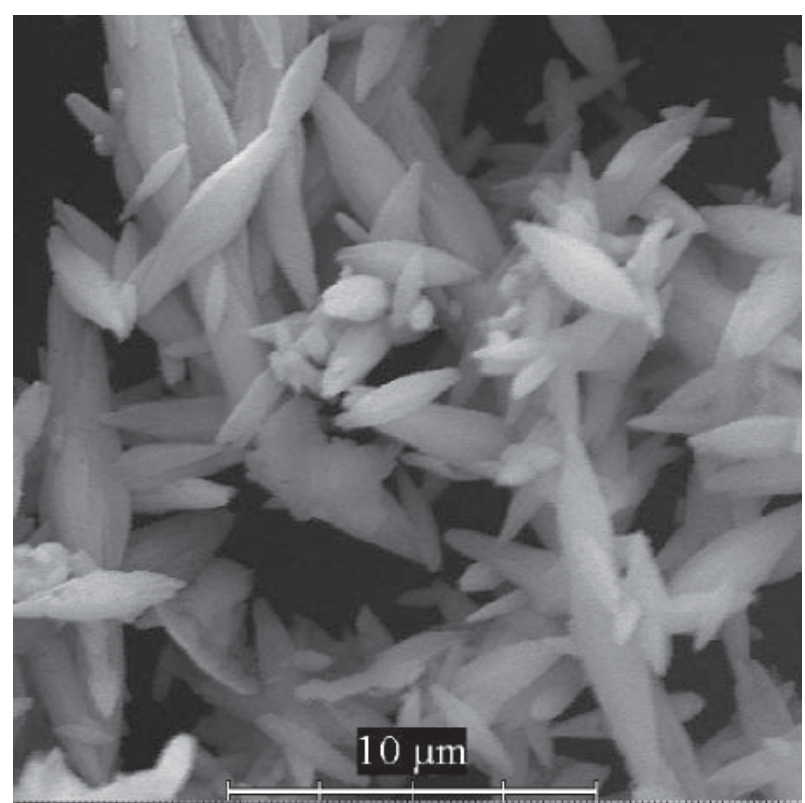

$3 \min$

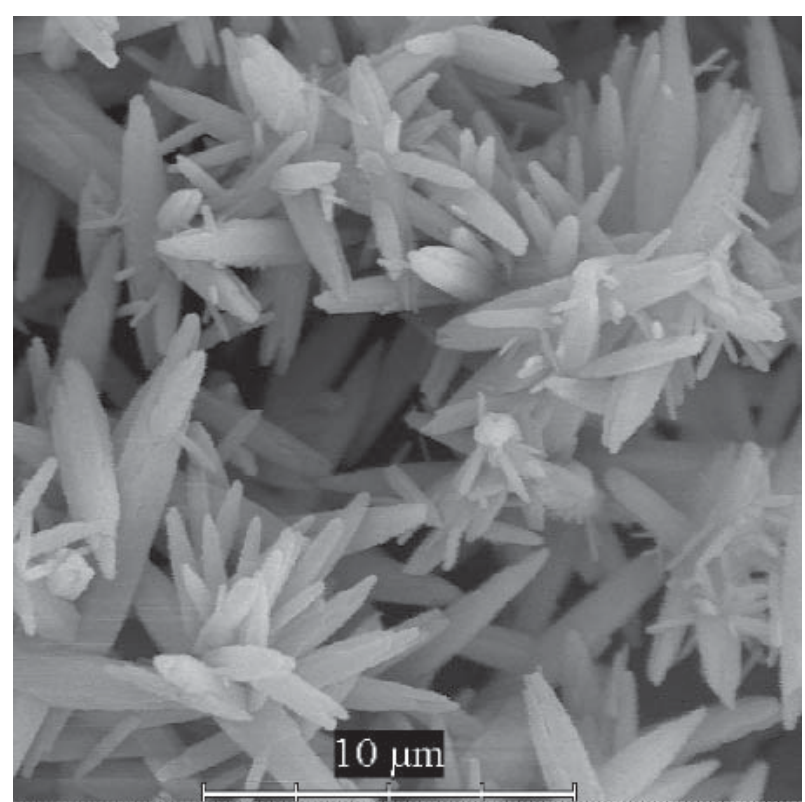

$15 \mathrm{~min}$

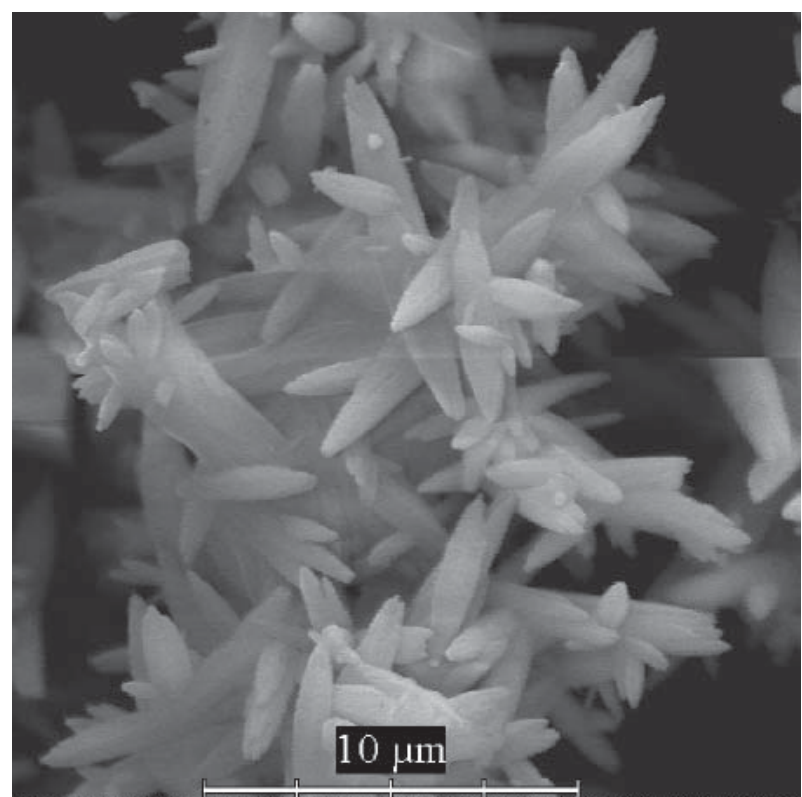

$9 \min$

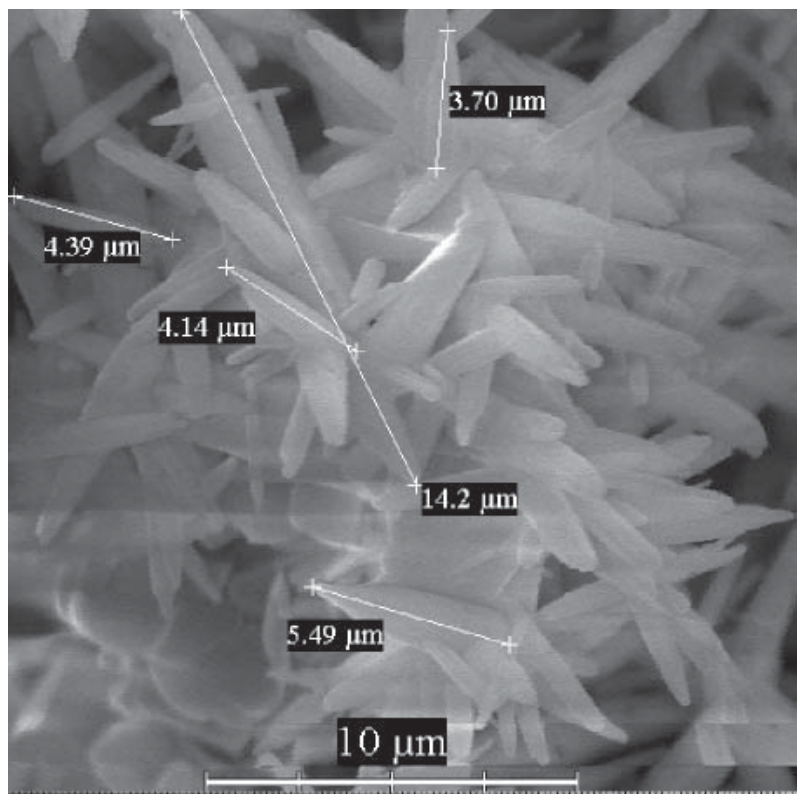

$18 \min$

Fig. 6. SEM of $\mathrm{CaCO}_{3}$ particles prepared at $70{ }^{\circ} \mathrm{C}$ depending on reaction time. 


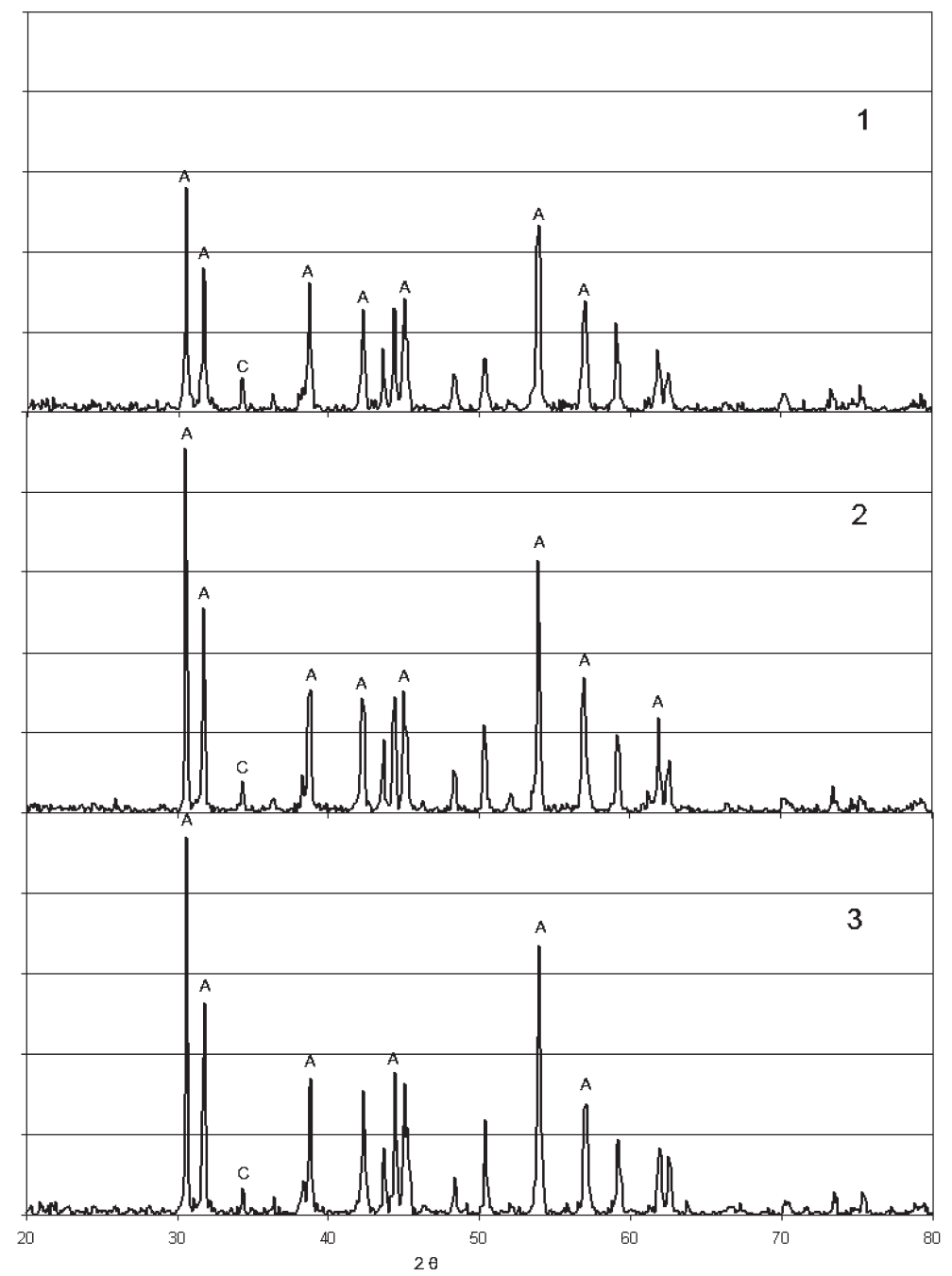

Fig. 7. X-ray diffraction of $\mathrm{CaCO}_{3}$ prepared at $70^{\circ} \mathrm{C}$; flow reactor; $1-1$. sampling, $2-2$. sampling, 3 - 3. sampling; A - aragonite, $\mathrm{C}-$ calcite.
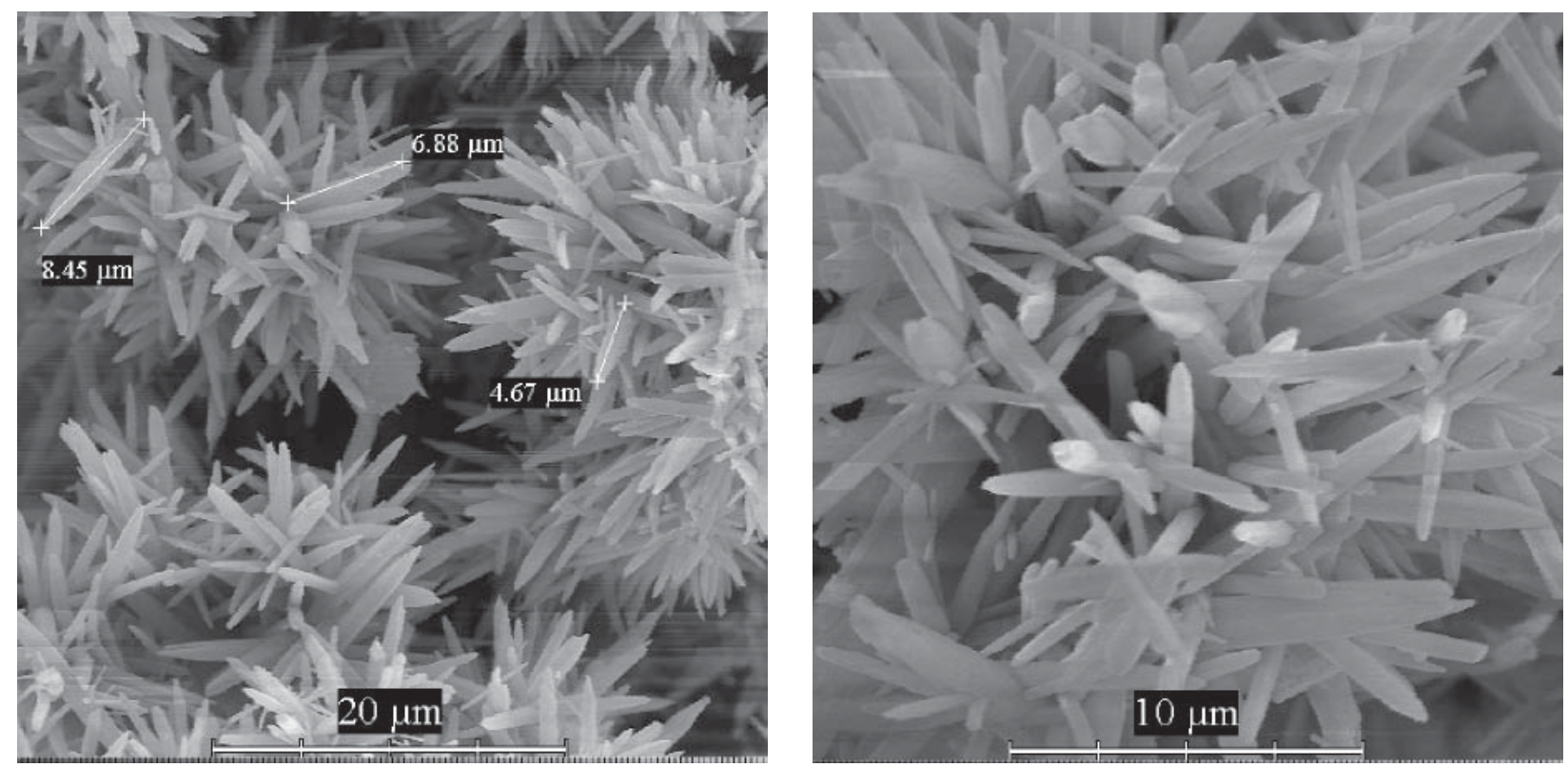

1 min flow reactor

Fig. 8a. $\mathrm{SEM}$ of $\mathrm{CaCO}_{3}$ particles prepared at $70{ }^{\circ} \mathrm{C}$; flow reactor. 

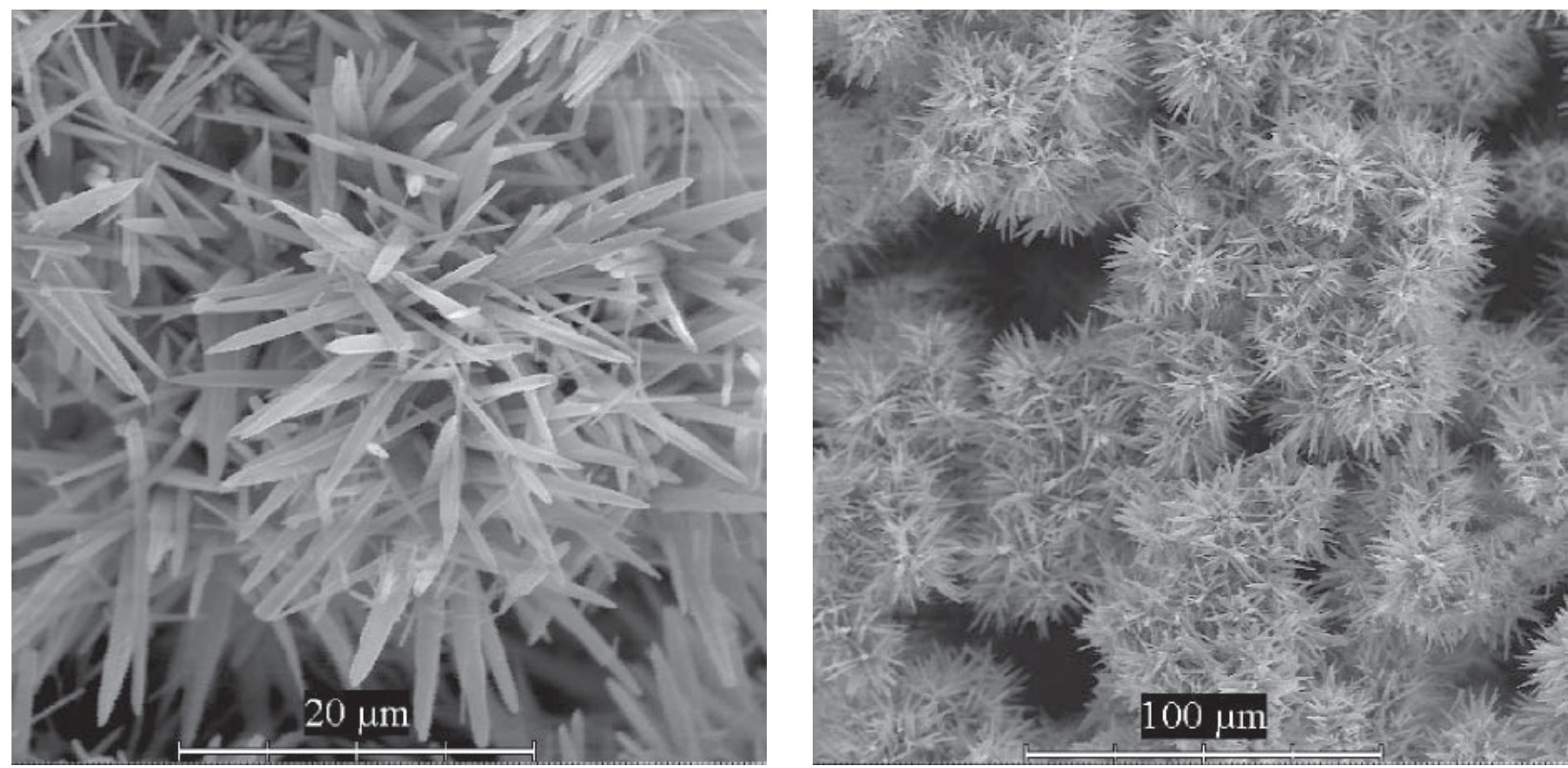

15 min flow reactor
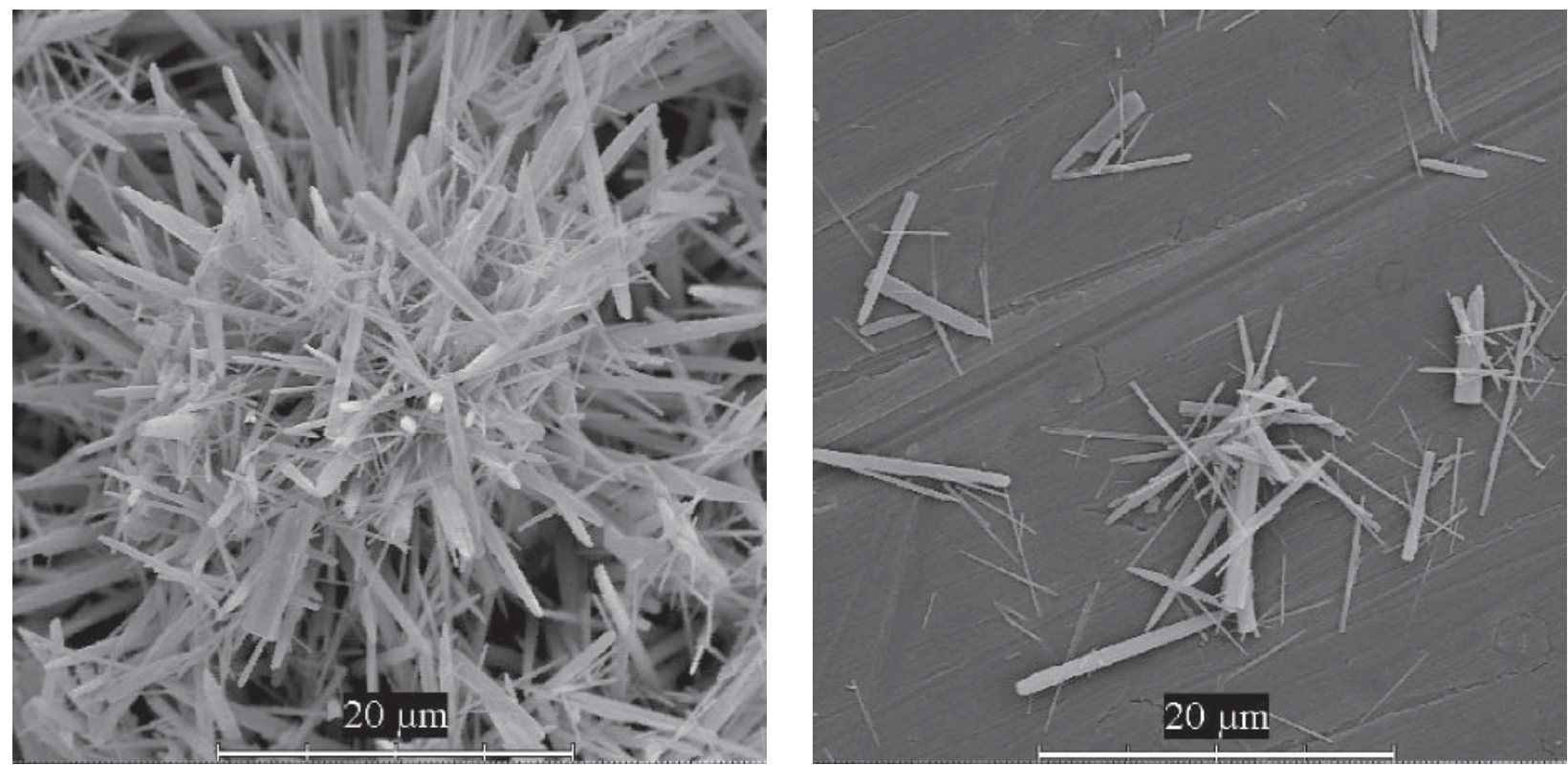

43 min flow reactor

Fig. 8b. SEM of $\mathrm{CaCO}_{3}$ particles prepared at $70{ }^{\circ} \mathrm{C}$; flow reactor.

the frit. Temperature of the reacting mixture was $(74 \pm 2)^{\circ} \mathrm{C}$. X-ray analysis proved (see Fig. 7) that under this condition almost pure aragonite (95\%) is formed.

Aragonite needles obtained after $1 \mathrm{~min}$ in flow reactor (1. sampling), $15 \mathrm{~min}$ (2. sampling) and $43 \mathrm{~min}$ (3. sampling) are shown in Fig. 8. It can be seen that needle-like crystals of different size are formed. After filtration and washing, $0.6 \%$ (with respect to dry solid) of dispersant (Polysatz cal - Na polyacrylat, Buyers) was added to the suspension (Fig. 9) containing $65 \mathrm{wt} \%$ of $\mathrm{CaCO}_{3}$. When required, the aragonite needles can be broken to shorter needles by mixing or grinding.

\section{Conclusion}

Needle-like aragonite particles for application in paper industry were prepared from calcium nitrate solution. Calcium nitrate was prepared from waste lime. Samples of precipitated aragonite were prepared both in batch and flow reactors, respectively. Prepared needle-like aragonite was successfully tested for application in paper industry. Conditions 

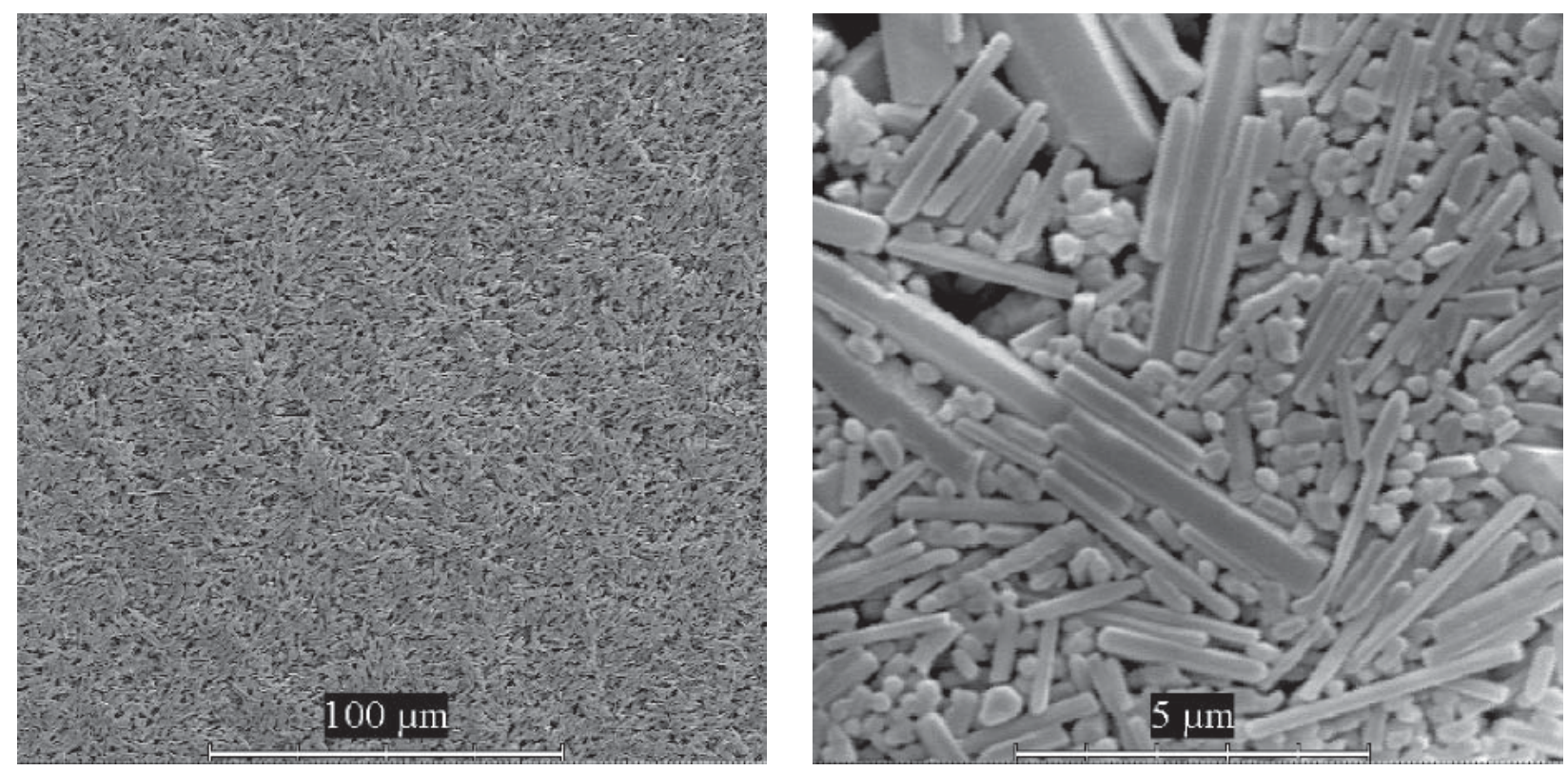

Fig. 9. SEM of 65 wt \% $\mathrm{CaCO}_{3}$ (aragonite $95 \%$ ) suspension prepared in the flow reactor. Precipitated product was disintegrated for $5 \mathrm{~min}$ in a mixer with $0.6 \%$ of dispersant.

(concentration of calcium nitrate, temperature, and flow rate of $\mathrm{CO}_{2}$ ) were optimized for achieving high yield of aragonite in the product (Patent application, 2011).

\section{Acknowledgement}

This work was supported by the project VMSP-P-0088-09 and by the Slovak Research and Development Agency under contract No. APVV-0203-07.

\section{References}

Elfil H, Roques H (2001) Desalination 137: 177-186.

Elfil H, Roques H (2004) AIChE Journal 50 (8): 1908-1916.

Fellner P, Jurišová J, Pach L (2011) Acta Chimica Slovaca $4(2): 3-10$.

Patent application "Method of production of needle-like aragonite from waste calcium hydroxide". PP; ÚPV-SR 00142-2011; Authors: Ladislav Pach, Pavel Fellner, Jana Jurišová (FCHPT STU Bratislava), Juraj Gigac, Štefan Boháček (VÚPC, Bratislava). 